\title{
GLOSA DO WYROKU WOJEWÓDZKIEGO SĄDU ADMINISTRACYJNEGO W GLIWICACH Z DNIA 1 LUTEGO 2013 R., SYGN. III SA/GL 1076/12
}

\author{
COMMENT ON THE JUDGEMENT \\ OF THE VOIVODSHIP ADMINISTRATIVE COURT \\ IN GLIWICE OF 1 FEBRUARY 2013, \\ III SA/GL 1076/12
}

\section{STRESZCZENIE}

Choć teza głosowanego wyroku, że organy nadzoru górniczego mogą podjąć określone czynności przewidziane prawem tylko w sytuacji, gdy nie został zakończony proces likwidacji zakładu górniczego bądź został zakończony nieprawidłowo jest trafna, to jednak wiele

" Prof. zw. dr hab., Kierownik Katedry Prawa Górniczego i Ochrony Środowiska na WPiA Uniwersytetu Śląskiego w Katowicach. 
okoliczności dotyczących stanu faktycznego, przyjętego jako podstawa wspomnianego orzeczenia, nie zostało wyjaśnionych. Spółdzielnia mieszkaniowa domagała się zabezpieczenia szybu górniczego, który dawno temu został zlikwidowany. Zdaniem organu nadzoru górniczego likwidacja ta została wykonana prawidłowo. Nie wiadomo jednak od kogo spółdzielnia mieszkaniowa żądała tego zabezpieczenia.

\section{Słowa kluczowe}

Nadzór górniczy; likwidacja zakładu górniczego; usunięcie zagrożenia.

\section{ABSTRACT}

However the thesis of the above judgement, that the mining authority may perform the activity provided by law only if a mining plant had not been properly closed or had been closed improperly is correct, numerous circumstances referring to the facts on which the above judgement is based, are unclear. The housing association demanded the protection of an old mining shaft which was considered as closed down many years before. The mining authority declared that shaft as properly closed down. It is not clear from whom the housing association demanded the protection.

\section{Keywords}

Mining authority; closing closure of a mining plant; threat removal.

\section{TEZA}

Organy nadzoru górniczego mogą podjąć określone czynności przewidziane prawem tylko w sytuacji, gdy proces likwidacji zakładu górniczego nie został zakończony, bądź został zakończony nieprawidłowo.

Wojewódzki Sąd Administracyjny w Gliwicach po roz2/2015 poznaniu na rozprawie sprawy ze skargi Spółdzielni Mieszka- 
niowej w Ś. na decyzję Prezesa Wyższego Urzędu Górniczego w przedmiocie ruchu i likwidacji zakładu górniczego (umorzenia postępowania w sprawie zabezpieczenia szybów oraz likwidacji szybu w byłym obszarze górniczym) oddala skargę.

Z uzasadnienia:

Prezes Wyższego Urzędu Górniczego (WUG) po rozpoznaniu odwołania Spółdzielni Mieszkaniowej (SM) w Ś., utrzymał decyzję Dyrektora Okręgowego Urzędu Górniczego (OUG) w G. umarzającą postępowanie w sprawie zabezpieczenia szybów I, II i „A” oraz likwidacji szybu III w byłym obszarze górniczym KWK „B” w Ś., w części dotyczącej zabezpieczenia szybów I, II i „A”. $\mathrm{Z}$ akt administracyjnych wynika, że Minister Spraw Wewnętrznych i Administracji (MSWiA) wyznaczył Dyrektora OUG w G., jako organ nadzoru górniczego właściwy rzeczowo w sprawie dotyczącej szybu nr III nieistniejącej kopalni w Ś. i zabezpieczenia pozostałych szybów. Działając na podstawie art. 105 k.p.a. organ I instancji umorzył postępowanie wskazując na brak podstaw do podjęcia dodatkowych działań zmierzających do poprawy istniejącego zabezpieczenia szybów I, II i „A”, bowiem nie występuje bezpośrednie zagrożenie bezpieczeństwa powszechnego (art. 81a ustawy z dnia 4 lutego 1994 r. - Prawo geologiczne i górnicze (Dz.U. z 2005 r. Nr 228, poz. 1947, ze zm., dalej: u.p.g.g.). Stwierdzone podczas wizji lokalnej zabezpieczenia tych szybów są wystarczające. Brak było podstaw do zobowiązania przedsiębiorcy do sprawdzenia prawidłowości rozwiązań technicznych zastosowanych przy likwidacji szybów I, II i „A” (art. 115 u.p.g.g.). W odniesieniu do szybu nr III w b. obszarze górniczym KWK „B” postępowanie administracyjne zostało zawieszone $\mathrm{z}$ uwagi na toczące się przed Sądem Okręgowym w K. postępowanie sądowe z powództwa Gminy Ś. przeciwko spółce akcyjnej o naprawienie szkody poprzez likwidację zapadliska tego szybu. SM wniosła o uchylenie tej decyzji i ponowne rozpatrzenie sprawy w części dotyczącej zabezpieczenia szybu „A", bowiem nie zachodzą przesłanki wskazujące na bezprzedmiotowość postępowania. Z opinii i ekspertyz sporządzonych w tej sprawie, a pominiętych w decyzji w sposób jednoznaczny wynika, iż istnieje realne zagrożenie bezpieczeństwa powszechnego. Z uzasadnienia wyroku wynika, że Sąd Okręgowy w K. 
nie wykluczył powstania szkody na „skutek odnowienia się poziomów wodonośnych i oddziaływania wody na materiał zasypowy". Bezpieczeństwo mieszkańców determinuje konieczność pozytywnego rozstrzygnięcia sprawy.

Prezes WUG utrzymał w mocy opisaną wyżej decyzję w mocy. Skarżąca wniosła o uchylenie zaskarżonej decyzji w części dotyczącej zabezpieczenia szybu „A”, zarzucając jej naruszenie art. $107 \S 3$ k.p.a., albowiem fakty uznane przez organ za udowodnione przeczą innym dowodom, którym odmówiono wiarygodności i mocy dowodowej. Jej zdaniem umorzenie postępowania podważa słuszność postanowienia MSWiA wyznaczającego organ nadzoru górniczego jako właściwy do orzekania w sprawie. W niniejszej sprawie chodzi o zapobieżenie szkodzie przez usunięcie zagrożeń, jakie nastąpiły wskutek źle przeprowadzonej likwidacji szybów na terenie byłej kopalni. Organ wniósł o oddalenie skargi podkreślając, że w zaskarżonej decyzji odniósł się zarówno do opinii wykonanej na zlecenie skarżącej, jak i opinii sporządzonej na zlecenie Sądu Okręgowego. Jego zdaniem organ I instancji rozpoczął merytoryczne rozpoznanie sprawy od przeprowadzenia wizji lokalnej. Wykazała ona, że zabezpieczenia szybów I, II i „A” są wystarczające. Uznanie, iż w przedmiotowej sprawie brak jest podstaw prawnych i faktycznych do merytorycznego rozpatrzenia sprawy przez organ nadzoru górniczego I instancji nie podważa słuszności postanowienia MSWiA wskazującego na organ nadzoru górniczego jako właściwy w przedmiotowej sprawie. Organ ten wszczął postępowanie administracyjne, zgromadził materiał dowodowy, który poddany został wnikliwej analizie, a następnie, nie znajdując podstaw prawnych do nakazania zabezpieczenia terenu, na którym znajduje się szyb „A”, umorzył postępowanie.

Skarga nie zasługuje na uwzględnienie. Stan faktyczny sprawy wynikający z uzasadnienia decyzji Prezesa WUG znajduje potwierdzenie $\mathrm{w}$ materiale dowodowym zgromadzonym w aktach sprawy (zob. Uchwała NSA z 15 lutego 2010 r. sygn. akt II FPS 8/09). Badając legalność zaskarżonej decyzji, Sąd nie stwierdził naruszenia przez organy administracji przepisów prawa materialnego ani procesowego w stopniu uzasadniającym 2/2015 jej uchylenie. Spór w rozpoznawanej sprawie dotyczy zasadności 
umorzenia decyzji pierwszoinstancyjnej. W myśl art. 105 k.p.a., gdy postępowanie z jakiejkolwiek przyczyny stało się bezprzedmiotowe w całości albo w części organ administracji publicznej wydaje decyzję o umorzeniu postępowania odpowiednio w całości albo w części. Z bezprzedmiotowością postępowania administracyjnego $\mathrm{w}$ rozumieniu art. $105 \S 1$ k.p.a. mamy do czynienia wówczas, gdy odpadł jeden z konstytutywnych elementów sprawy administracyjnej. Przyczyny, dla których sprawa będąca przedmiotem postępowania administracyjnego utraciła charakter sprawy administracyjnej lub nie miała takiego charakteru jeszcze przed wszczęciem postępowania, mogą być różnorodnej natury. W Wyroku NSA z dnia 18 kwietnia 1995 r. (SA/Łd 2424/94, ONSA 1996, nr 2, poz. 80) przyjęto, że: „Z bezprzedmiotowością postępowania mamy do czynienia wówczas, gdy w sposób oczywisty organ stwierdzi brak podstaw prawnych i faktycznych do merytorycznego rozpatrzenia sprawy". W Wyroku z 10 maja 2012 r. (sygn. II GSK 467/11, LEX nr 1219036) NSA stwierdził, że „istota bezprzedmiotowości postępowania polega na tym, że nastąpiło takie zdarzenie prawne lub faktyczne, które spowodowało, że przestała istnieć ta szczególna relacja między faktem (sytuacją faktyczną danego podmiotu) a prawem (sytuacją prawną danego podmiotu), z którą prawo łączy obowiązek konkretyzacji normy w postaci wydania decyzji administracyjnej".

Z dniem 1 stycznia 2012 r. weszła w życie Ustawa z 9 czerwca 2011 r. Prawo geologiczne i górnicze (Dz.U. Nr 163, poz. 981). W myśl jej art. 222 do postępowań wszczętych przed dniem wejścia w życie ustawy stosuje się dotychczasowe przepisy. W niniejszej sprawie należy zatem stosować przepisy Ustawy z 4 lutego 1994 r. Prawo geologiczne i górnicze. W myśl jego art. 81 ust. 1 „Do likwidacji zakładu górniczego stosuje się odpowiednio przepisy o ruchu zakładu górniczego”, a „Plan ruchu likwidowanego zakładu górniczego powinien w szczególności przewidywać sposób wykonania obowiązków określonych w art. 80” (ust. 2). Wedle art. 81 a) ust. 1 u.p.g.g.: „W razie niewykonania obowiązku likwidacji zakładu górniczego lub jego oznaczonej części, organ nadzoru górniczego nakazuje przedsiębiorcy, w drodze decyzji, wykonanie tego obowiązku". Orga- 
ny nadzoru górniczego mogą zatem podjąć określone czynności przewidziane prawem tylko w sytuacji, gdy nie został zakończony proces likwidacji zakładu górniczego bądź został zakończony nieprawidłowo. Mogą też badać prawidłowość stosowanych rozwiązań.

Organ nadzoru górniczego prawidłowo wszczął postępowanie w sprawie zabezpieczenia szybów I, II i „A”. W jego trakcie przeprowadzono wizję lokalną stwierdzając, że rejon szybów I, II i III oraz szybu „A” jest prawidłowo zabezpieczony. Z notatki służbowej wynika, że rejon szybu „A” jest ogrodzony płotem betonowym o wysokości $1,8 \mathrm{~m}$. W płocie znajduje się zamknięta na kłódkę drewniana brama. Wlot do szybu jest zabezpieczony płytą betonową. Organy obu instancji powołały się również na opinię biegłego, posiadającego wiadomości specjalne z zakresu likwidacji szybów oraz zabezpieczenia terenu pogórniczego, sporządzoną na zlecenie Sądu Okręgowego w K., dotyczącą sposobu likwidacji szybu nr III. Wynika z niej, że likwidacja szybów była przeprowadzona zgodnie z obowiązującymi w tym czasie przepisami oraz wiedzą. Skoro organ nadzoru górniczego stwierdził zakończenie procesu likwidacji szybu, zasadnym stało się umorzenie postępowania. Konstatacji tej nie stoi na przeszkodzie twierdzenie skarżącej o potencjalnym zagrożeniu i przywoływane przez nią opinie, wedle których w rejonie szybu "A" istnieje potencjalne zagrożenie wystąpienia zapadlisk.

W przedmiotowej sprawie nie ma podstaw prawnych i merytorycznych do rozpatrzenia sprawy. Wedle art. 6 k.p.a. organy administracji publicznej działają na podstawie przepisów prawa, zaś w u.p.g.g. brak jest przepisu, który zezwalałby organowi nadzoru górniczego na podjęcie działań w przypadku stwierdzenia potencjalnego zagrożenia, które może nastąpić w przyszłości w przypadku wystąpienia splotu różnych okoliczności.

Nie ma racji skarżąca twierdząc, że umorzenie postępowania podważa słuszność postanowienia MSWiA wyznaczającego Dyrektora OUG w G. jako właściwego rzeczowo organu nadzoru górniczego w sprawie. Powoływanie się strony skarżącej na toczone sprawy cywilne dotyczące roszczeń strony skarżącej wobec innych podmiotów będących następcami prawnymi kopalni 2/2015 nie ma wpływu na rozpoznawaną sprawę administracyjną. 


\section{GLOSA}

Stan faktyczny stanowiący podstawę komentowanego wyroku nie został przedstawiony dostatecznie jasno. Można przypuszczać, że likwidacja kopalni w Ś. obejmowała m.in. wchodzące w jej skład szyby, do czego zapewnie doszło dawno temu. W ocenie skarżącej SM przyczyną powstałego ostatnio zagrożenia (a częściowo zapadliska) była wadliwie wykonana likwidacja. Nie wiadomo jednak od kogo skarżąca domagała się wspomnianego zabezpieczenia, a zwłaszcza czy istniał przedsiębiorca prowadzący wspomnianą (już zlikwidowaną) kopalnię bądź jego następca prawny. Skoro równocześnie toczył się spór sądowy o naprawę szkody powstałej w wyniku zapadliska szybu III, można zakładać, że (przynajmniej w ocenie skarżącej SM) istniał podmiot odpowiedzialny za taką szkodę, w tym niewykluczone, że spoczywałby na nim obowiązek dokonania zabezpieczeń.

Nie wiadomo również kiedy dokonano likwidacji wspomnianych szybów. Ustalenie tej daty może jednak być okolicznością pozbawioną większego znaczenia w sprawie. Istota obowiązków likwidacyjnych ma charakter zuniwersalizowany i nie ulega zróżnicowaniu w zależności od tego, pod rządem jakich przepisów były one wykonywane ${ }^{1}$. Bezspornie natomiast spór zainicjowany został pod rządem prawa geologicznego i górniczego z 1994 r. $^{2}$, a w konsekwencji jego rozwiązania mają kluczowe znaczenie dla sprawy.

Skoro wspomniane szyby wchodziły w skład zakładu górniczego to szczegóły dotyczące ich likwidacji winien określić tzw. plan ruchu likwidowanego zakładu górniczego, zatwierdzany w drodze decyzji organu nadzoru górniczego. Obowiązek takiej likwidacji spoczywał na prowadzącym wspomniany zakład

1 Wymagania dotyczące likwidacji zakładu górniczego pojawiły się za sprawą Ustawy z dnia 16 listopada 1960 r. o zmianie prawa górniczego, Dz.U. nr 52, poz. 302 .

2 Ustawa z dnia 4 lutego 1994 r., t.j. Dz.U. 2005 r. nr 228, poz. 1947 ze zm., cyt. jako: u.p.g.g.1994. 
(przed 1994 r. na przedsiębiorstwie górniczym, a od dnia wejścia w życie u.p.g.g.1994 na przedsiębiorcy ${ }^{3}$ ). Automatycznie pojawia się zatem problem stron postępowania. Co prawda bezspornie zostało ono zainicjowane przez SM, to jednak powinno się ono toczyć z udziałem tego podmiotu, na którym (w ocenie wnioskodawcy) spoczywał obowiązek likwidacji wspomnianych szybów (bądź jego następcy prawnego). Głosowany wyrok zdaje się nie dostrzegać tego problemu. Wiadomo natomiast, że gmina (jako poszkodowana) domagała się od spółki akcyjnej naprawienia szkody powstałej w wyniku zapadnięcia się szybu III, czego dotyczył spór toczący się przed Sądem Okręgowym. Inaczej mówiąc, gmina uważała wspomnianą spółkę akcyjną za następcę prawnego podmiotu odpowiedzialnego za likwidację pozostałych szybów, który w konsekwencji ponosi odpowiedzialność za szkodę spowodowaną zapadliskiem. Jak wynika z uzasadnienia głosowanego wyroku, decyzje organów obu instancji skierowane zostały wyłącznie do SM. Być może organy nadzoru górniczego wyszły z założenia, że przedsiębiorca (jego następca prawny) już nie istnieje, ale z uzasadnienia głosowanego wyroku nie wynika, aby którykolwiek organ orzekający w sprawie badał tę okoliczność. Skoro zaś SM dochodziła roszczeń odszkodowawczych od spółki akcyjnej należało zbadać czy nie powinna ona stać się stroną postępowania w przedmiocie wnioskowanych przez nią zabezpieczeń. Nie wiadomo również, z czego wnioskująca SM wywodziła swój interes prawny w zakresie zgłoszonego żądania. Można domyślać, się, że - w odniesieniu do zapadliska szybu III - interes ten wynikał ze stanu zagrożenia szkodą. Brak natomiast informacji czym miał on być uzasadniony w odniesieniu do zabezpieczenia pozostałych szybów. Sąd orzekający w sprawie nie dostrzegł tych problemów.

Nie kwestionując ustaleń dotyczących prawidłowości likwidacji szybów I-II oraz „A” zwrócić należy uwagę, że skoro w rejonie szybu III (w odniesieniu do którego postępowanie zostało zawieszone, a w uzasadnieniu głosowanego wyroku brak informacji o jego podjęciu) doszło do powstania zapadliska, to

3 W rozumieniu art. 6 u.p.g.g.1994, co jednak nie ma znaczenia dla sprawy. 
zachodzi co najmniej przypuszczenie, że jego likwidacja mogła być wykonana wadliwie.

Z punktu widzenia tematu istotne jest natomiast, że w świetle art. 81a u.p.g.g.1994 (znajdującego zastosowanie do zaskarżonej decyzji) w razie niewykonania obowiązku likwidacji zakładu górniczego lub jego oznaczonej części,organ nadzoru górniczego na drodze decyzji nakazuje przedsiębiorcy wykonanie tego obowiązku, określając termin jego wykonania. Bezskuteczny upływ terminu uzasadnia wdrożenie postępowania egzekucyjnego (ust. 1-2). W razie wątpliwości przyjmuje się, że taka decyzja upoważnia do niezbędnego w jej wykonaniu korzystania z cudzej nieruchomości (ust. 4). Nawet jeżeli, jak to przyjęto $\mathrm{w}$ przedmiotowym sporze, likwidacja została wykonana prawidłowo i nie zachodziła potrzeba wykonania robót zabezpieczających, wykazanie tej okoliczności (prowadzące do umorzenia postępowania) winno nastąpić z udziałem wszystkich stron.

Powstaje natomiast pytanie: na kim powinny spoczywać obowiązki związane $\mathrm{z}$ zabezpieczeniem nienależycie zlikwidowanych obiektów zakładu górniczego (np. szybów) czy też takich, które w ogóle nie zostały zlikwidowane w sytuacji, w której nie istnieje przedsiębiorca (który dotychczas prowadził taki zakład górniczy) bądź jego następca prawny. Istota tego problemu znakomicie wykracza zresztą poza problematykę stanowiącą przedmiot prawa geologicznego i górniczego ${ }^{4}$ i stale nabiera na aktualności. Jedną z konsekwencji restrukturyzacji przemysłu staje się bowiem konieczność odpowiedzi na pytanie: na kim spoczywa obowiązek usunięcia niepożądanych następstw dotychczasowej działalności ujawnionych po likwidacji podmiotu, który ją prowadził. Pół biedy jeżeli ten ostatni uległ przekształceniu $\mathrm{w}$ sposób pozwalający na ustalenie następcy prawnego. Likwidacja takiego podmiotu może natomiast zostać dokonana w sposób, który wykluczy wspomniane następstwo. Innym przykładem może być sytuacja polegająca na niewypłacalności zobowiązanego i to nawet w stopniu, który wykluczy możliwość ogłoszenia upadłości. Problem ten ma walor nie tyl-

${ }^{4}$ Ustawa z dnia 9 czerwca 2011 r., t.j. Dz.U. 2014, poz. 613 ze zm. 
ko teoretyczny, a sytuacje tego rodzaju nie są odosobnione. Wymagania prawa określające wymagania związane z likwidacją działalności przemysłowej oraz odpowiedzialnością za stan środowiska odnoszą się do podmiotu, który prowadził taką działalność, co stanowi wyraz powszechnie aprobowanej zasady „zanieczyszczający płaci” (zob. art. 7 Ustawy z dnia 27 kwietnia 2001 r. - Prawo ochrony środowiska5). Niewypłacalność bądź brak takiego podmiotu (jego następcy prawnego) automatycznie powodują powstanie pytania, na kim takie obowiązki mają spoczywać. W prawie polskim nie istnieje norma prawna odnosząca się do wszystkich tego rodzaju przypadków. Znane są sytuacje, w których rozwiązanie tego problemu wymagało jednostkowej interwencji ustawodawcy, czego przykładem jest Ustawa z dnia z dnia 14 lipca 2000 r. o restrukturyzacji finansowej górnictwa siarki ${ }^{6} \mathrm{w}$ jej pierwotnym brzmieniu. Co prawda od 1994 r. istnieje możliwość uzależnienia koncesji (m.in. na wydobywanie kopalin) od zabezpieczenia roszczeń powstałych w wyniku prowadzonej na jej podstawie działalności, tyle że w praktyce instytucja ta pozostaje martwą literą prawa. Od 2002 r.7 przedsiębiorca wydobywający kopalinę obowiązany jest gromadzić środki na przyszłą likwidację zakładu górniczego tworząc tzw. fundusz likwidacji zakładu górniczego. Rozwiązanie nie działa jednak wstecz, a nadto z różnych powodów może okazać się nieskuteczne, chociażby z powodu utraty bytu prawnego takiego podmiotu. Nieco inaczej przyjęto natomiast w Ustawie z dnia 7 września 2007 r. o funkcjonowaniu górnictwa węgla kamiennego ${ }^{8}$. Zakłada ona, że likwidacja „kopalni” następuje $\mathrm{w}$ zasadzie $\mathrm{w}$ oparciu o środki wspomnianego funduszu. Nie każdy dostrzeże różnicę. Pojęcie „kopalni” jest bowiem szersze od pojęcia „zakładu górniczego”, podczas gdy środki wspomnianego funduszu w górnictwie węgla kamiennego usta-

5 T.j. Dz.U. 2013, poz. 1232 ze zm.

6 Dz.U. nr 74, poz. 856 ze zm. Zob. również Ustawę z dnia 30 sierpnia 2013 r. o dotacji przeznaczonej dla niektórych podmiotów, Dz.U. 2013, poz. 1160.

7 Zob. Ustawę z dnia 27 lipca 2001 r. o zmianie ustawy Prawo geologiczne i górnicze, Dz.U. nr 110, poz. 1190.

8 Dz.U. Nr 192, poz. 1379 ze zm. 
la się w oparciu o wartość środków trwałych tworzących zakład górniczy. W odniesieniu do niektórych „kopalń” koszt likwidacji pokrywany jest „z dotacji budżetowej”, a zatem ze środków Skarbu Państwa.

Stan faktyczny stanowiący podstawę zaskarżonego wyroku nie pozwala odpowiedzieć na pytanie, czy istniał przedsiębiorca górniczy (jego następca prawny), na którym spoczywał obowiązek zabezpieczenia wspomnianych szybów. Można przypuszczać, że wiązały się z tym wątpliwości, czego dowodem był spór o naprawę szkody w postaci zapadliska szybu III toczący się przed sądem cywilnym. Nie wiadomo również kto i kiedy wykonał likwidację wspomnianych szybów, jaki obowiązywał wówczas stan prawny ${ }^{9}$, a nadto na czym (w ocenie SM) polegał stan zagrożenia.

Wedle art. 96 (w zw. z art. 99) u.p.g.g. 1994 w razie braku przedsiębiorcy odpowiedzialnego za szkodę albo jego następcy prawnego roszczenia o naprawę szkód spowodowanych ruchem zakładu górniczego bądź o zapobieżenie im przysługują przeciwko Skarbowi Państwa reprezentowanemu przez właściwy miejscowo organ nadzoru górniczego ${ }^{10}$. Powstaje pytanie, czy z tej podstawy prawnej można wywodzić obowiązek usunięcia zagrożenia spowodowanego wadliwie wykonaną likwidacją zakładu górniczego (zabezpieczenia wadliwie zlikwidowanych szybów). Co najmniej częściowo można na nie odpowiedzieć pozytywnie, tyle że wyłącznie w płaszczyźnie stosunków cywilnoprawnych. Jeżeli nie istnieje przedsiębiorca (jego następca prawny), a w związku z prowadzonym w przeszłości ruchem (już zlikwidowanego) zakładu górniczego powstał stan zagrożenia szkodą, roszczenie o jej zapobieżenie przysługuje w stosunku do Skarbu Państwa reprezentowanego przez właściwy miejscowo organ nadzoru górniczego. O ile zatem SM wykazałaby stan

9 Można przypuszczać, że zlikwidowana kopalnia prowadziła działalność w zakresie wydobywania węgla kamiennego. Jeżeli tak, to należało ustalić, czy do wspomnianej likwidacji znajdowała zastosowanie któraś z ustaw poświęconych reformie górnictwa węgla kamiennego.

10 Tak samo przewiduje art. 146 ust. 4 (w zW. z art. 150) aktualnie obowiązującego prawa geologicznego i górniczego. 
zagrożenia szkodą, mogłaby żądać od Skarbu Państwa podjęcia stosownych działań zapobiegawczych (prewencyjnych), tyle że w postępowaniu przed sądem cywilnym. Odrębnym problemem może natomiast być termin przedawnienia takiego roszczenia.

Gdyby zaś usunięcie takiego stanu zagrożenia wymagałoby likwidacji wyrobisk górniczych (np. szybu) oraz obiektów i urządzeń pozostałych po zakończeniu wydobywania kopaliny w byłym zakładzie górniczym, wówczas związane z tym szczegóły musiałby określić plan ruchu likwidowanego zakładu górniczego (art. 80 u.p.g.g.1994), zatwierdzany przez organ nadzoru górniczego. Nie mógłby jednak być nim właściwy miejscowo dyrektor okręgowego urzędu górniczego. Ten ostatni musiałby bowiem zostać wyłączony od orzekania w sprawie (art. $24 \S 1$ pkt 1 k.p.a.).

Analiza głosowanego wyroku uzasadnia zatem ocenę, że organy administracji orzekające w sprawie mogły uchybić obowiązkowi wszechstronnego wyjaśnienia wszystkich istotnych okoliczności sprawy (art. 7 i 77 k.p.a.), a nadto postępowanie mogło toczyć się z pominięciem jego stron. Nikt nie dostrzegł też, że w świetle art. 82a u.p.g.g.1994 przepisy rozdziału o likwidacji zakładu górniczego stosuje się odpowiednio do likwidacji wyrobisk górniczych oraz obiektów i urządzeń pozostałych po zakończeniu wydobywania kopaliny w byłym zakładzie górniczym, prowadzonej przez podmioty inne niż określone w art. $29^{11} \mathrm{i}$ art. $80^{12}$. Ta enigmatyczna formuła wymaga wyjaśnienia. Zasadą jest (i było $\mathrm{w}$ stanie prawnym obowiązującym $\mathrm{w}$ dacie podjęcia zaskarżonej decyzji), że obowiązek likwidacji zakładu górniczego (jego oznaczonej części) spoczywał na przedsiębiorcy w rozumieniu u.p.g.g.1994 (tak samo jest pod rządem u.p.g.g.2011). Obowiązek ten nie ulegał (i nie ulega nadal) wyłączeniu w sytuacji, w której dany podmiot utracił koncesję i w

11 Wedle którego cofnięcie albo wygaśnięcie koncesji nie zwalnia dotychczasowego przedsiębiorcy z wykonania obowiązków dotyczących ochrony środowiska oraz obowiązków związanych z likwidacją zakładu górniczego (ust. 1).

12 Wedle którego obowiązek likwidacji zakładu górniczego spoczywa na przedsiębiorcy (ust. 1). 
rezultacie przestał być przedsiębiorcą. Mogło (i nadal) dojść do następstwa prawnego $\mathrm{w}$ zakresie skutków prawnych wynikających z prawa geologicznego i górniczego, czego przykładem w zakresie górnictwa węglowego mogą być rozwiązania wspomnianej Ustawy z dnia 7 września 2007 r. bądź obowiązujących przed datą jej wejścia w życie ustaw poświęconych restrukturyzacji tej gałęzi gospodarki.

W konkluzji należy dojść do wniosku, że o ile teza głosowanego wyroku (stanowiąc konsekwencję rozwiązań wynikających $\mathrm{z}$ art. 7 Konstytucji oraz art. 6 k.p.a.) zasługuje na aprobatę, o tyle jego uzasadnienie nasuwa wątpliwości co do zgodności rozstrzygnięcia z prawem ${ }^{13}$.

\section{Kontakt e-mail:}

aleksander.lipinski@us.edu.pl

13 NSA w dniu 2 października 2014 r. (sygn. akt II GSK 1358/13) oddalił skargę kasacyjną na glosowany wyrok. Wedle informacji znajdującej się (wedle stanu na dzień 16 marca 2015 r.) w Centralnej Bazie Orzeczeń Sądów Administracyjnych miało to nastąpić w drodze „postanowienia”. Okoliczność ta nie polega jednak na prawdzie. Oddalenie skargi nastąpiło w drodze wyroku, co wynika z informacji uzyskanej w WUG. 